very small scale that it has in the past ; in which case the law should be amended and added to in order to safeguard the interests of the small number of parents, medical men and children involved, where these are threatened. There would seem, too, to be a parallel here with the law regarding abortion. This is illegal except where the mother's health is endangered. Would it not be possible that artificial insemination--donor might be made illegal, too, except on the same grounds ?

The findings of the Commission are that "assisted insemination" between husband and wife may be justified and, with one dissentient, that artificial insemination-husband may also be justified; but that artificial insemination-donor is wrong in principle and contrary to Christian standards. It is further recommended that "early consideration should be given to framing of legislation to make the practice a criminal offence".

It is pleasant to turn to the minority report by Dr. W. R. Matthews, the Dean of St. Paul's, who did not feel that he could sign the report. While everyone may not be in complete agreement with his views, all can admire the spirit which inspires them. He admits that he, like almost every normal person, finds the subject repugnant; but he does not, therefore, think that this necessarily makes it wrong. $\mathrm{He}$ says of the Commission: "We should have done better if we had been content to state what we believe to be the proper attitude of Christians to A.I.D. in the present circumstances, while reserving the question of its absolute condemnation in all circumstances to further study"- -an opinion which many puzzled people of goodwill are likely to endorse.

'Lancet, 463 (Sept. 18, 1948).

\section{THE JOHN INNES} \section{HORTICULTURAL INSTITUTION}

$\mathrm{T}$ HE John Innes Horticultural Institution is perhaps best known in the scientific world for its great part in genetical work, under its three successive directors, Bateson, Hall and Darlington. While its contributions to science in the field of cytogenetics have been so outstanding, sight must not be lost of the more directly horticultural research in the applied sphere which has steadily progressed at the Institution and which has resulted in advances of knowledge no whit less important. Throughout, the work has been a model of what applied research should be, the scientific approach to the problems of the practical grower. The work of M. B. Crane on compatibility and incompatibility in fruits illustrates this conception of applied research in a striking manner ; not only does it constitute an outstanding advance in scientific knowledge, but also it is the foundation of all modern systems of orchard planning. His "Fertility Rules in Fruit Planning" (Leaflet No. 4 of the new collected edition of the John Innes Leaflets*) is the vade mecum of all growers laying out new plantations.

No less important to the horticulturist is the work of W. J. C. Lawrence on the preparation of soil composts for glasshouse plants. The aim throughout the work has been the standardization of materials

* The Fruit and the Soil: Collected Edition of the John Innes Leaflets. Edited by C. D. Darlington. Pp. viii +62, (London: Olive and Boyd, 1948.) 38. $6 d$. net. and methods so that growers anywhere may rely upon reproducible results of proved excellence. It is a further and a large step in the direction of what is, after all, the goal of every grower-complete control over every phase of a plant's growth to the greater benefit of man's nutritional and rsthetic needs. Those who cavil at new scientific ideas as "interference with Nature' should pause for a moment to consider how every operation the gardener undertakes is 'interfering' with 'natural' processes.

In this collected edition of leaflets, prepared, as the preface states, "in order to put the grower, the gardener, and the seedsman into touch with the latest results of research", a new leaflet on serd production has been added. This is of first importance to the horticulturist because it summarizes information which is difficult to find in print elsewhere. The classification of field and garden crops by degrees of cross-pollination, the methods of isolation by time and distance, and the distinction between the needs of commercial and stock seed are vitally important to all who embark upon the difficult work of seed growing.

The John Innes Institution has done great work for the horticulturist, and when it has settled into its new home at Bayfordbury, with the enormously greater potential facilities it will have, we may look forward to a new series of these practical, yet wholly scientific, leaflets.

R. H. StoughtoN

\section{FORTHCOMING EVENTS}

(Meetings marked with an asterisk * are open to the public)

Monday, November 15

MANChester Literary and PhILOSOPHICAL SOcIETY (in the Reynolds Hall, College of Technology, Manchester), at 5.30 p.m.Prof. L. Rosenfeld: "Conceptions of Force in Physics" (Wilde Memorial Lecture).*

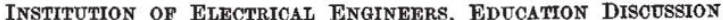
CIRCLE (at Savoy Place, Victoria Embankment, London, W.C.2), at 6 p.m.-Discussion on "What Fundamental Principles should be Mhould they be Introduced ?"' (to be opened by Prof. J. T. MacGregorMorris).

ROYAL GEOGRAPHICAL SOCTETY (at Kensington Gore, London, S.W.7), at 8.15 p.m.-Capt. D. P. Mason : "New Discoveries in British Antarctica".

Tuesday, November 16

UNIVERSITY COLLEGE, LONDON (in the Anatomy Theatre, Gower Street, London, W.C.1), at 1.15 p.m.-Dr. S. J. F. Philpott: "PsychoStreet, London, W.C.1), at 1.15 p.m.- - Dr. S. J. F. Philpott: "Psychology as a science

ROYAL SOCIETY OF ARTS, Dominions AND Colonies SECTION (at John Adam Street, Adelphi, London, W.C.2), at 2.30 p.m.-Dr. Basil F. J. Schonland, F.R.S.: "Recent Scientific Developments in South Africa".

SOCIETY OF ChEMTCAL INDUSTRY, AGRICULTURE GROUP (in the Chemistry Department, Royal College of Science, Imperial Institute Road, London, S.W.7), at 2.30 p.m.-Mr. A. Muir: "Soil Survey and Soil Classification". ROYAL INSTITUTION (at 21 Albemarle Street, London, W.1), at
5.15 p.m.-Dr. S. F. Birch : "Recent Advances in the Chemistry of H.15 p.m.-Dr. S. F. Birch : "Recent Advances in the Chemistry of Hydrocarbons"

institution of Euectrical Engineers, Measurements Section (at Savoy Place, Victoria Embankment, London, W.C.2), at 5.30 p.m. -Discussion on "Measurement of Telecommunications Efficiency" (to be opened by Mr. W. West).

Society of Chemical Industry, Plastics Group (at the Institution of Mechanical Engineers, Storey's Gate, St. James's Park, London, S.W.1), at 5.30 p.m.-Prof. J. Kendall, F.R.S. : "Leo Hendrik Baekeland and the Development of Phenolic Plastics" (Baekeland Memorial

INSTITUTION OF THF RUBBER INDUSTRY (at Caxton Hall, Caxton Street, London, S.W.1), at 7 p.m.-Dr. W. D. Rae: "Dielectric Heating of Rubber".

Royal Statistical Society, TeEs-Side Sub-group of THE INDUSTRIAL APPLICATIONS SECTION (at the Cleveland Scientific Institution, Middlesbrough), at 7.15 p.m.-Mr. L. T. Wilkins: "Incentives and the Young Worker". (To be repeated on Wednesday, November 17 , at 6.30 p.m., at the Newcastle Chemical Industries Club, 18 Lovain Place, Newcastle-upon-Tyne.) 